$v$ 


\title{
Identifying a Relict Cultural Landscape. The Lower Danube Limes in Bulgaria
}

\author{
Silva Sabkova
}

DOI:10.17234/9789531757799.4

National Archaeological Institute with Museum Bulgarian Academy of Sciences

2 Saborna Str.

BG-1000 Sofia, Bulgaria

s.s.sabkova@gmail.com

The Danube Limes is a relict cultural landscape, part of the Frontiers of the Roman Empire. It consists of three main material elements: defensive structures, infrastructure and landscape. What binds together these elements and turn them into a cultural landscape are the relationships between them. The principal challenge when studying such kind of cultural landscapes is their identification within the contemporary landscape as many of their elements are invisible or destroyed, the original character of the surroundings is altered and, as a result, many of the original relationships are hard to detect.

To face this challenge this paper proposes a methodology for analysis of the territory, designed to guide the process of identification of the cultural landscape Lower Danube Limes in Bulgaria in view of its protection as a cultural heritage site. Each fortified location is evaluated according to a set of criteria regarding the present state of the site and its surroundings in comparison with their past state, in view of their authenticity and integrity. The methodology facilitates the detection of: preserved valuable elements of both archaeological sites and landscape; relationships that each site has with other locations or with the landscape; risk factors affecting the property.

The result of the analysis may serve as a basis for the designation of protected areas and other measures for the protection of the cultural landscape.

\section{The Lower Danube Limes in Bulgaria as a part of the Frontiers of the Roman Empire}

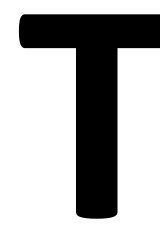

he Lower Danube Limes in Bulgaria is part of the Frontiers of the Roman Empire and more precisely of the frontier which goes along the Danube from its spring to its delta on the Black Sea. This is one of the most long-lasting defensive lines that stably retain its function and geographical position through the ages - from the beginning of the $1^{\text {st }}$ c. - as part of the Roman Empire, up to the $7^{\text {th }}$ c. - already as part of the Eastern Roman Empire Byzantium. The Bulgarian section of the Danube has a length of about $471 \mathrm{~km}$ and there are around 80 known fortified sites belonging to the Lower Danube limes situated around it. 
The frontiers of the Roman Empire are one of the main instruments for the security of the empire, designed not only to demarcate but also to protect its territory. They secure the empire from invasions, protect the territory and population from attacks and raidings by small groups, provide control of the flow of people and access to imperial territory (Breeze 2011: 194-212). This is accomplished through the symbiosis between humans represented by the Roman army, and the environment in which the army operates - including built facilities (artificial barriers, forts and minor military posts, roads) and natural resources.

Nowadays the former frontiers of the Roman Empire lie on the territory of a number of countries in Europe, North Africa and the Middle East ${ }^{1}$. However, their common past as part of one integral system led to the idea of the formation of a single trans-border cultural heritage site of world significance (UNESCO FRE 2008: 153; Fejérdy and Jilek 2011: 20). The first section, which has been inscribed individually on the World Heritage List, is the Hadrian's Wall in 1987. In 2005 as World Heritage was declared also the Upper Raetian Limes in Germany and in 2008 - the Antonine's wall; they are now united as one transnational serial property "Frontiers of the Roman Empire" (FRE) (Fig. 1).

The final objective is the association of all the remaining parts of the FRE in Europe and elsewhere.In Europe, the remaining sections of the frontiers are these in the present-day Netherlands and Upper Germany, the whole Danube limes, which concerns Germany, Austria, Slovakia, Hungary, Croatia, Serbia, Bulgaria and Romania and the Dacian frontier in Romania. Up to now, most of the above-mentioned states (except for Romania) have included their sections in their respective national tentative lists for cultural heritage. (UNESCO FRE TL 2016; UNESCO FRE WHS Slovakia). ${ }^{2}$

According to the present day definition ${ }^{3}$ of the FRE WHS, the Frontiers of the Roman Empire as cultural heritage site are defined as relict cultural landscape: "The remains include the lines of the linear frontier, natural elements such as the sea, rivers and deserts, and networks of military features such as roads on, behind and beyond the frontier. These encompass both visible and buried archaeology. Together the inscribed remains and those to be nominated in the future form an extensive relict

1 UK, The Netherlands, Germany, Austria, Slovakia, Hungary, Croatia, Serbia, Bulgaria, Romania, Turkey, Syria, Jordan, Israel, Iraq, Egypt, Libya, Tunisia, Algeria, and Morocco (SOUV 2012: 1)

2 In the meanwhile, after the submission of this paper, Romania also added their sites to their tentative list in 2018.

3 Included within the Statement Of Outstanding Universal Value For The Frontiers Of The Roman Empire And Its Component Parts and within the summary nomination statement of the FRE. cultural landscape which displays the unifying character of the Roman Empire, through its common culture, but also its distinctive responses to local geography and political and economic conditions. Each component part is a substantial reflection of the way resources were deployed in a particular part of the Empire." (SOUV 2012; similar in FRE SNS 2004: 1-2; UNESCO FRE 2008: 449).

\section{The Lower Danube Limes as a cultural landscape. Problems}

The Danube Limes as every Roman frontier is a system composed of three main material elements: landscape, different types of fortifications and defensive structures, and infrastructure (Fig. 2).

- The landscape - the natural surroundings are the original primary context in which all the man-made structures are integrated. The demarcation line of the frontier, in this case, is the river Danube itself.

- The characteristics of this pre-existent natural background - the Danube riverbank - define the locations of the primary fortification structures: the earliest and strategically most important points for the defence or for the further expansion - fords on the Danube, the mouths of its major tributaries as their valleys lead deep into the territory, in other words, the places where the naturally defined routes pass across the border.

- The word Limes has been used initially in the sense of military road, and only later was adopted for the fortified frontier itself (Elton 1996: 70-1; Torbatov 2004: 77; Breeze 2011: 6). The infrastructure has always been a priority for the Romans, so simultaneously with the establishment of the primary fortification structures, starts the construction of the main military road (in this case the Danube Limes road) that connects them and facilitates the mobility of the imperial army troops and the exchange of goods.

- As the main road is the spine of the economical and cultural exchange and is indispensable for the operation of the frontier's defence its safety and functioning has been secured further with the construction of secondary defensive structures. These fill the gaps between the primary fortifications; they are often situated at naturally protected locations that allow the surveillance of the surroundings.

The characteristics and topography of the territory determine generally the location, typology and nature of the Romans military structures. On the other hand, the presence of a series of functionally bound man-made 


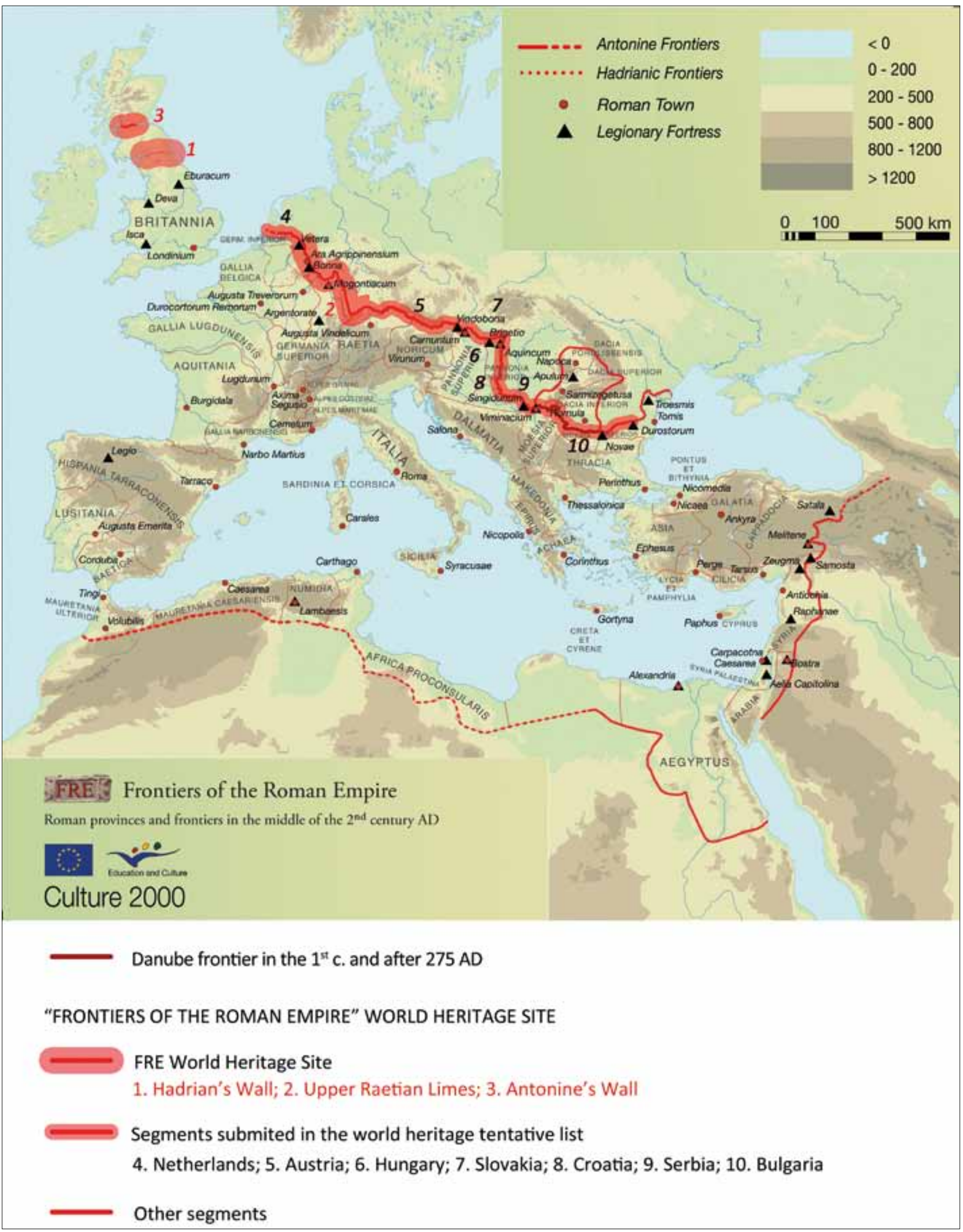

FIGURE 1. The Frontiers of the Roman Empire and "Frontiers of the Roman Empire" World Heritage Site (Base map original author: Frontiers of the Roman Empire Culture 2000 project (2005-2008); WHS layer and legend by Silva Sabkova) 
FIGURE 2. The symbiosis between cultural heritage and natural environment forming the relict cultural landscape Lower Danube Limes in Bulgaria

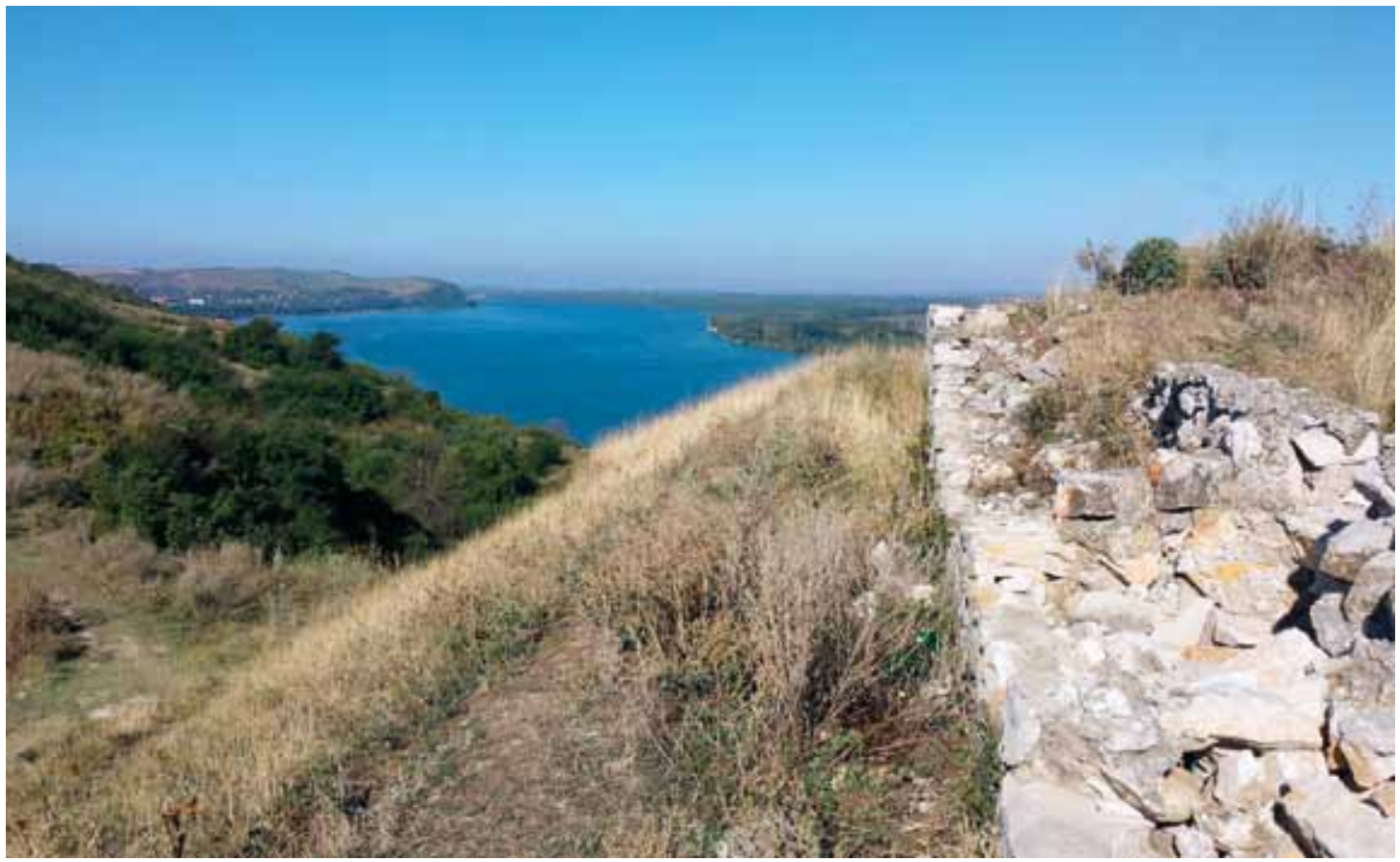

elements, subject to an overall strategic plan, gives the territory itself a new aspect. This combination of natural and anthropic elements belonging to the past forms the relict cultural landscape (Fig. 3).

One of the serious issues regarding a relict cultural landscape like the Danube Limes in Bulgaria, is that its features are not quite obvious; the system has ceased to function many centuries ago, its elements have been degraded by a number of factors and many of them are not even visible anymore, there is no prominent artificial barrier that may tie together the whole system, the original environment has been altered. Therefore, the question what has to be considered as subject of protection does not really have an obvious answer.

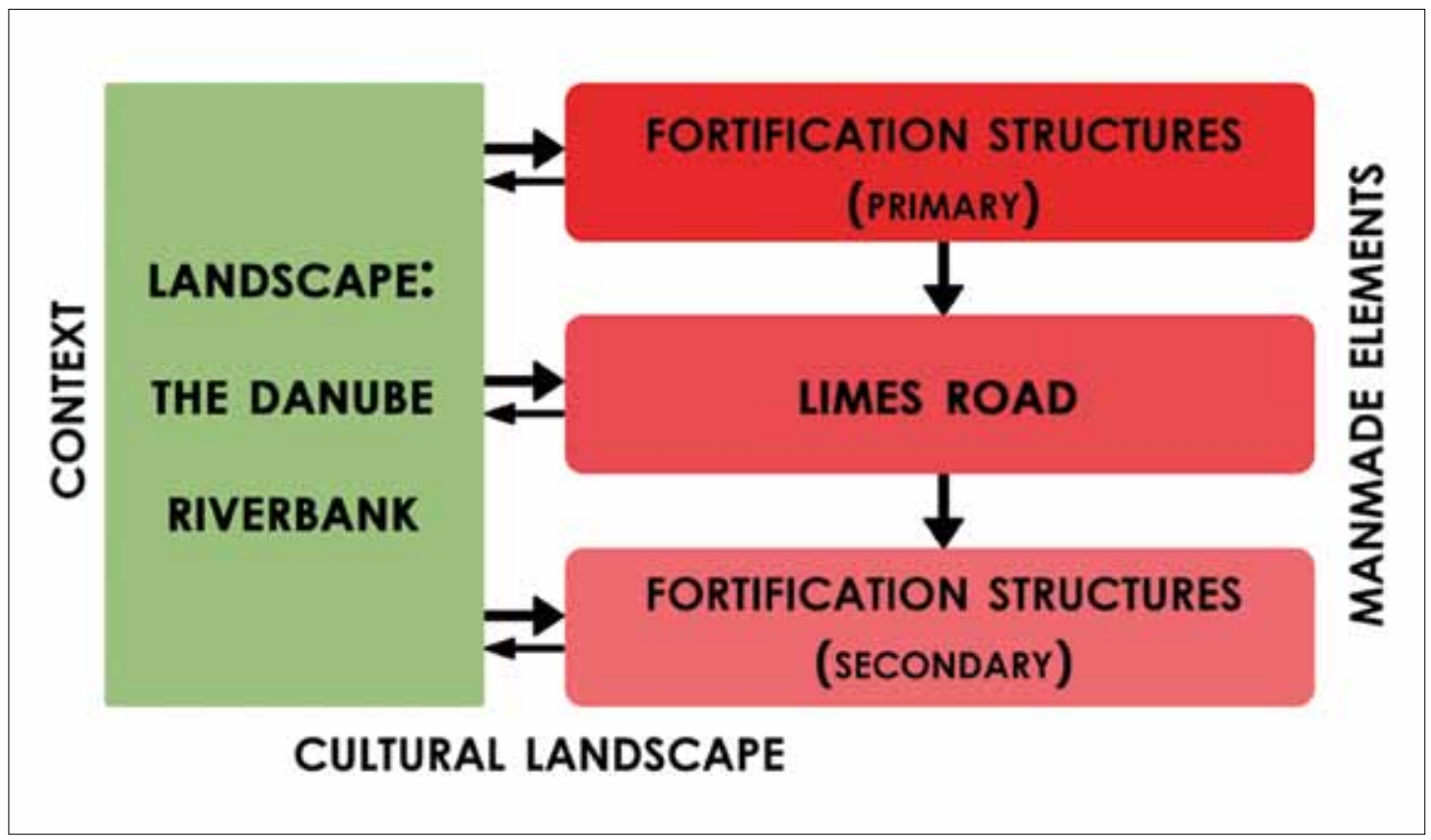

FIGURE 3. The Danube Limes and the relations between its elements as a cultural landscape 
Presently, the very limited number of legally protected sites belonging to the Danube Limes in Bulgaria ${ }^{4}$ makes it obvious that there is still a lack of comprehension about the concept of cultural landscape. The sites that benefit from legal protection are mainly those having visible remains. Those are protected only as individual sites and neither their fundamental characteristic to make part of a larger system, nor the question about their context has ever been taken into consideration. This limited selection of sites cannot represent and make the Danube Limes understandable as a system that involves landscape and artefacts alike.

This paper aims to raise the awareness towards all the less prominent elements of the cultural landscape of the Lower Danube Limes in Bulgaria that however contribute to its integrity and authenticity.

\section{Integrity and authenticity of the Lower Danube Limes}

Integrity and authenticity of a World Heritage Site such as the "Frontiers of the Roman Empire" is the sum of the degree of integrity and authenticity of all the various elements that compose it - man-made or natural, regardless of their size. Therefore in order to express the Outstanding Universal Value of the Lower Danube Limes in Bulgaria, the authenticity and integrity ought to be demonstrated at system level though demonstration of preserved integrity and authenticity in as many individual sites as possible and integrity and authenticity of the relationships site to site, site to landscape, site to system.

The authenticity and integrity of a site do not end with its material remains. The surroundings of each site and the territory between the sites should also be analysed in view of their authenticity and integrity. Obviously, the environment along the Danube river bank is much altered due to natural or anthropic factors and it is often unauthentic. However, each individual case should be analyzed in order to determine to what extent the relationship between site and environment is altered or compromised; sometimes the altered ground cover does not necessarily change the relationship between the site and its surroundings. Preserved features or elements

4 The Bulgarian section of the Danube limes has been submitted on 01 April 2016. It includes 27 fortifications, one stone quarry, and 5 road fragments with or without pavement. This means that more than the half of the known sites has been discarded from the selection for inclusion in the tentative list of Republic of Bulgaria. The sites selected for inclusion are however the best examples of sufficiently studied and provenly existing sites, usually with visible remains. This approach focusing on the best examples of sites may be practical, but it is certainly not very sensitive towards the preservation of the integrity and the authenticity of the cultural landscape, which requires inclusion of as many sites as possible, those invisible as well. revealing an authentic aspect of the historic character of the landscape, relevant to the archaeological sites should also be traced. The integrity and authenticity at system level include also visual integrity.

The inclusion of the maximum amount of elements and relationships as part of the subject of protection would contribute to the better preservation and enhancement of the integrity and authenticity of the Danube Limes. It will also increase the possibility to make more understandable the structure and the unity of the frontier as a system, rather than a sum of individual fortified sites. It would add another layer of perception to those sites and will enrich the experience of the interested public.

\section{Preliminary researches and database.}

To get started understanding what should be included in the subject of protection in the case of the Lower Danube Limes in Bulgaria it is necessary to collect as much relevant information as possible. It will be later used to plan and design the instruments of protection. The main archaeological sites that form the backbone of the cultural landscape Lower Danube Limes in Bulgaria (all known fortified locations, despite their size) should be used to form the backbone of a specifically designed GIS-based database. The present paper aims to outline the contents of such database that should be prepared in near future.

A site from the Lower Danube Limes will be used to illustrate the graphic visualisation of the contents of the proposed database and the analysis that follows. This is Colonia Ulpia Oescus (Gigen, Pleven, Bulgaria) (Fig. 4).

The first step is to collect basic descriptive information about each fortified location on which the analysis and evaluation of the valuable elements and relationships will be later based. The sources that should be used to compile this initial basic database include reports from archaeological excavations, aerial recognition, remotesensing and of course most importantly - field surveys and observations. It should also be implemented with other kinds of existing GIS-based databases that are useful for the understanding and management of the cultural landscape, such as land use, land cover, cadastre, natural protected areas, territorial building plans, etc.

Naturally, the level of detail that should be visualised depends on the scale. In view of the preparation of the nomination of the Bulgarian section as part of FRE WHS, it is practical to adopt the standard scales for such documentation. The contents of the standard mapping materials for the nomination are predominantly descriptive and schematic in nature, and contain information about 
FIGURE 4. Ulpia Oescus: Decumanus, shops and bath-house (personal archive, 2016).

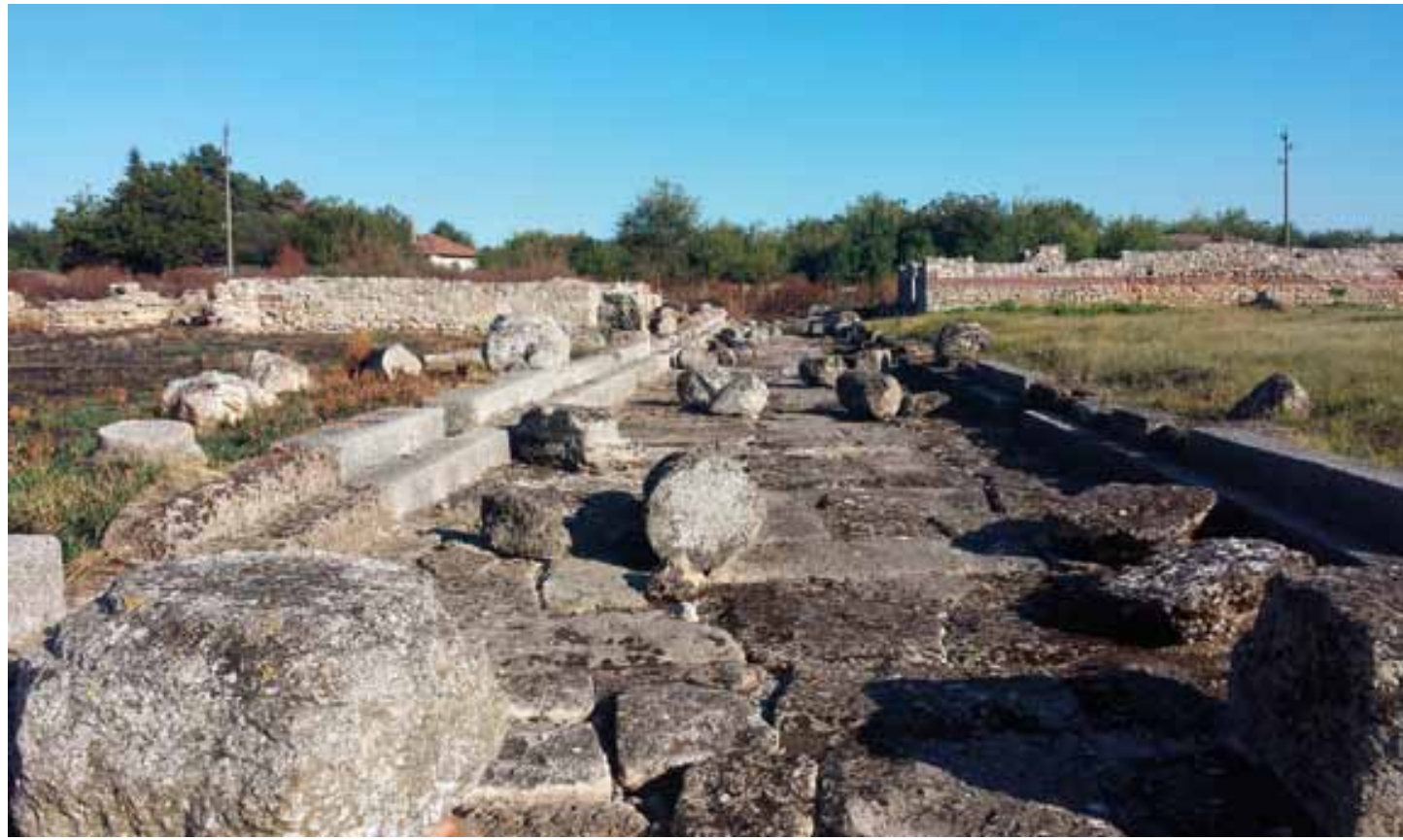

the location of the fortifications and the artificial barriers (if any), towers and other structures represented by their area on a real scale, distinguishing them according to their visibility (visible, invisible, supposed, destroyed). It contains the outline of the proposed WHS and the buffer zone as well as the boundaries of legal protection under the national law (if available). The standard scales are 1 : 50000/25000 and 1: 5000 (Jones and Thiel 2008: 99-100, Fejérdy and Jilek 2011: 13-15).

While the scales are adopted, the contents however of the GIS-based database designed specifically for the study and management of the Lower Danube Limes in Bulgaria and respectively of the maps that may be produced from, should be much extended and should include data from the preliminary research, needed for the designation of boundaries of the potential WHS and buffer zone. There are multiple levels of information that have to be available on both scales. The geographic background should be able to switch between satellite imagery, topographic maps and geo-referenced historical aerial footage. Data from other GIS services should be incorporated, such as data about the land cover and land use, protected areas, cadastre.

The scale 1:50000/25000 is used for the representation and analysis of larger sections; includes all the sites and their vaster surroundings. It includes representation of the areas (known or provisory) of all primary and secondary sites true to the scale. The distinction between visible and invisible sites should be made. This scale should be used for analysis of valuable relationships at the system level: visual relationships between the pri- mary sites, between primary sites and secondary sites, relationships between the sites and the landscape, historic and current road connections.

The basic scale for the analysis is 1:5000. At this scale, the focus is on the individual sites and their immediate surroundings. It contains information about the actual remains at each site, contains a plan of the site (according to archaeological research or aerial recognition); current land use; boundaries of heritage and natural protection; tourist infrastructure. A distinction should be made between visible and invisible elements within each site. This scale should be used for analysis of valuable or problematic elements and relationships within the site itself and its surroundings.

The boundaries of each location should be described with geographical coordinates and the polygon describing each site should be associated with a number of attributes. These polygons should cover the actual physical boundaries of the sites established by destructive or non-destructive research methods. It should be noted that in certain cases where the sites have legal boundaries of protection already assigned they may not coincide with the real physical boundaries. Both should be included in the database. The attribute table for the polygons describing the main sites should contain the categories listed in Table 1, with the possibility to choose one or more respective predefined values or in some cases to add some free text. These options then may be used to sort, filter and visualize the sites according to the objectives of the analysis of the territory of the cultural landscape (Fig. 5). 


\begin{tabular}{|c|c|c|c|c|}
\hline Category & Values & Sub values & Free text & Visualization \\
\hline \multirow{4}{*}{$\begin{array}{l}\text { Visibility } \\
\text { (of the remains) }\end{array}$} & $\begin{array}{l}\text { Visible } \\
\text { (presence of any } \\
\text { visible structures) } \\
\end{array}$ & & (optional) & \multirow{4}{*}{$\begin{array}{l}\text { On a smaller the } \\
\text { scale, sites with visible } \\
\text { structures should be } \\
\text { distinguished graphically } \\
\text { by those that don't } \\
\text { have visible structures. } \\
\text { On a larger scale, all } \\
\text { visible and invisible but } \\
\text { known remains should } \\
\text { be represented on the } \\
\text { cartographic overlay } \\
\text { with the possibility to } \\
\text { distinguish between } \\
\text { them. }\end{array}$} \\
\hline & \multirow[b]{2}{*}{$\begin{array}{l}\text { Invisible } \\
\text { (absence of structures } \\
\text { visible above ground) }\end{array}$} & $\begin{array}{l}\text { Presence of surface } \\
\text { scattered materials }\end{array}$ & (optional) & \\
\hline & & $\begin{array}{l}\text { Absence or } \\
\text { impossibility to detect } \\
\text { surface scattered } \\
\text { materials }\end{array}$ & (optional) & \\
\hline & $\begin{array}{l}\text { Destroyed } \\
\text { (there must be } \\
\text { evidence that the site } \\
\text { has been completely } \\
\text { destroyed) }\end{array}$ & & (optional) & \\
\hline \multirow{4}{*}{$\begin{array}{l}\text { Chronology }{ }^{5} \\
\text { (of the visible / } \\
\text { known / presumed } \\
\text { archaeological } \\
\text { remains) }\end{array}$} & pre-Roman & & \multirow{4}{*}{$\begin{array}{l}\text { If possible, it is } \\
\text { recommendable to } \\
\text { include provisory dates } \\
\text { of establishment and } \\
\text { final destruction of the } \\
\text { fortifications. }\end{array}$} & \multirow{4}{*}{$\begin{array}{l}\text { Each period should be } \\
\text { distinguished by colour. }\end{array}$} \\
\hline & Roman & Principate & & \\
\hline & 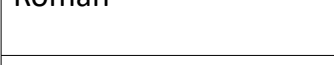 & Late Antiquity & & \\
\hline & Medieval & & & \\
\hline \multirow{7}{*}{$\begin{array}{l}\text { Typology } \\
\text { (of the site) }\end{array}$} & Legionary camp & & - & \multirow{7}{*}{$\begin{array}{l}\text { The various type of sites } \\
\text { should be distinguishable } \\
\text { graphically from one } \\
\text { another }\end{array}$} \\
\hline & & Infantry & - & \\
\hline & Auxinary & Cavalry & - & \\
\hline & \multirow{3}{*}{$\begin{array}{l}\text { Fortified city / } \\
\text { settlement }\end{array}$} & Colonia & - & \\
\hline & & Municipium & - & \\
\hline & & Other settlement & - & \\
\hline & Watch tower & & - & \\
\hline \multirow{12}{*}{$\begin{array}{l}\text { The character of the } \\
\text { present environment }\end{array}$} & \multirow{3}{*}{ Agricultural areas } & Arable land & - & \multirow{12}{*}{$\begin{array}{l}\text { This information may be } \\
\text { obtained from already } \\
\text { existing data bases such } \\
\text { as Corine Land Cover } \\
\text { Europe } 2012 \text {. Each type } \\
\text { of environment should } \\
\text { be visualised according } \\
\text { to a standardised colour } \\
\text { scheme. }\end{array}$} \\
\hline & & Orchards & - & \\
\hline & & Vineyards & - & \\
\hline & \multirow{5}{*}{$\begin{array}{l}\text { Urban } \\
\text { (Artificial surfaces) }\end{array}$} & Continuous & - & \\
\hline & & Discontinuous & - & \\
\hline & & Low storey & - & \\
\hline & & High storey & - & \\
\hline & & Industrial & - & \\
\hline & \multirow{3}{*}{$\begin{array}{l}\text { Natural } \\
\text { (Forests and semi- } \\
\text { natural areas, } \\
\text { wetlands) }\end{array}$} & Forest & - & \\
\hline & & Natural grassland & - & \\
\hline & & Wet areas & - & \\
\hline & Water Bodies & & - & \\
\hline
\end{tabular}




\begin{tabular}{|c|c|c|c|c|}
\hline Category & Values & Sub values & Free text & Visualization \\
\hline \multirow{5}{*}{$\begin{array}{l}\text { Cultural heritage } \\
\text { protection }\end{array}$} & Archaeological reserve & - & \multirow{5}{*}{$\begin{array}{l}\text { Protection regimes: free } \\
\text { text according to the act } \\
\text { of declaration }\end{array}$} & \multirow{5}{*}{$\begin{array}{l}\text { If boundaries are } \\
\text { available they should } \\
\text { be described with } \\
\text { coordinates and } \\
\text { visualized graphically on } \\
\text { the cartographic overlay }\end{array}$} \\
\hline & World significance & - & & \\
\hline & National significance & - & & \\
\hline & Local significance & - & & \\
\hline & Serial Property & - & & \\
\hline \multirow[t]{2}{*}{ Natural protection } & Yes & & $\begin{array}{l}\text { Protection regimes: free } \\
\text { text according to the act } \\
\text { of declaration }\end{array}$ & $\begin{array}{l}\text { Their boundaries may } \\
\text { be integrated from } \\
\text { already existing GIS- } \\
\text { based databases such } \\
\text { as: Protected Areas in } \\
\text { Bulgaria: Available at: } \\
\text { http://eea.government. } \\
\text { bg/flexviewers/pr-areas/ } \\
\text { index.html? }\end{array}$ \\
\hline & No & & & \\
\hline \multirow{2}{*}{$\begin{array}{l}\text { Excavations and } \\
\text { surveys }\end{array}$} & Yes & - & \multirow{2}{*}{$\begin{array}{l}\text { What has been } \\
\text { researched } \\
\text { Bibliography }\end{array}$} & \\
\hline & No & - & & \\
\hline \multirow{2}{*}{$\begin{array}{l}\text { Conservation / } \\
\text { Restoration }\end{array}$} & Yes & - & \multirow{2}{*}{$\begin{array}{l}\text { What has been done } \\
\text { References }\end{array}$} & \\
\hline & No & - & & \\
\hline \multirow{2}{*}{ Accessibility } & Yes & - & \multirow{2}{*}{ (optional) } & \multirow{2}{*}{$\begin{array}{l}\text { Data about road } \\
\text { accesses, public } \\
\text { transport may be } \\
\text { imported from existing } \\
\text { GIS databases }\end{array}$} \\
\hline & No & - & & \\
\hline \multirow{2}{*}{ Socialization } & Yes & - & \multirow{2}{*}{ (optional) } & \multirow{2}{*}{$\begin{array}{l}\text { Visit routes, services } \\
\text { and facilities, parking } \\
\text { lots should be included } \\
\text { graphically }\end{array}$} \\
\hline & No & - & & \\
\hline \multirow{2}{*}{ Maintenance } & Yes & - & \multirow{2}{*}{ (optional) } & \\
\hline & No & - & & \\
\hline
\end{tabular}

TABLE 1. The layout of the attribute table for the Danube Limes sites.

The system should provide the possibility to make references between main and secondary sites associated with the main site. Those sites should all be listed within a secondary but similar database and should be described with similar attributes.

"Typology of the site" this time should include: civilian settlements, suburban estates, industrial and mining complexes, cemeteries, sacred sites, ports and possibly others.

The Danube limes road should be regarded as a special category.

5 Naturally all Danube Limes sites are Roman by definition, but in some cases there is continuity and the remains from other periods happen to be more prominent.

\section{Identifying the relict cultural landscape Lower Danube Limes in Bulgaria.}

The actual recognition of the elements and relationships that partake in the cultural landscape and the evaluation of their level of integrity and authenticity should be then based on one hand on analysis of the information included in the database, that concern mostly the current state of the sites and the system, but on the other - it should involve knowledge about the history of the transformations occurred in each site, in the landscape, in the infrastructure, in the structure of the system on a territorial level, etc.. 
What is of uttermost importance is to consider the state of the environment in the past, during the functioning of the Lower Danube Limes. Despite its distance in time, it is still possible to have at least a general idea about the land cover and the state of the major elements of the environment such as relief and water bodies.

The study of the natural component of the cultural landscape - the environment and the complex transformation processes that concern it, require an interdisciplinary approach, based on the conclusions from existing researches from different fields: geography, geomorphology, botany, archaeology, history and others, combined with information coming from other sources: classical sources, historical maps, materials from archives and field observations. The exploration of the present and past transformations of the natural environment and building up hypotheses about what it may have been in Roman times provided background information needed for the detection of certain valuable elements and relationships having direct relativity to the structure and organization of the man-made elements of the system. Even if they are still present in the territory today, they often could not be associated so easily with the Danube Limes cultural landscape at their present state. When possible, this data should be also implemented into the GIS-based database in order to facilitate its use during the analysis.

For example, having an idea about what the authentic environment of the Danube Limes may have been, allows identification of preserved historic elements of the landscape in close relation to the fortified locations old riverbeds, the character of the vegetation, wetlands and others. These elements are often directly related or determinative for the choice of the particular location as suitable for fortification in Roman times. Therefore these elements should be treated as part of the cultural landscape and should be included in the system for preservation and management alongside the man-made structures. In other cases, even though the character of the landscape has been completely changed, it has been established that the present situation has something in common with the historic one, for example lack or presence of development or/and high vegetation in certain areas around the site. It means that the visual

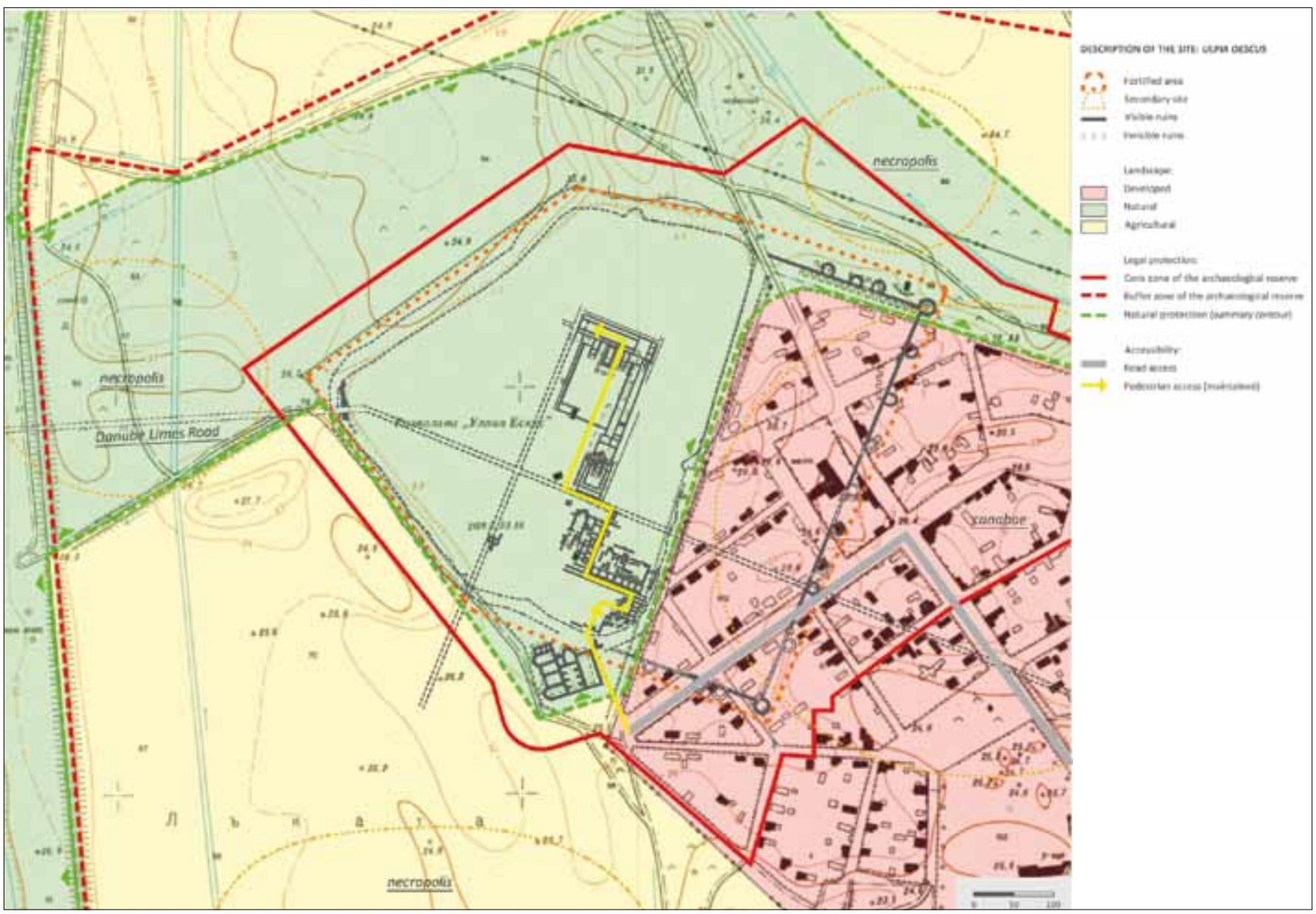

Figure 5. Description of Ulpia Oescus. Plan according to existing research (after St. Daskalova in Ivanov T. and Ivanov R. 1998: 57, fig. 24), placed on topographic map K-3-36-(40) (1979). 
relationship between the site and its environment in the respective direction is similar to the authentic one and it is worth preserving it.

The man-made component of the Danube Limes includes a variety of artificial elements that make part of the cultural landscape. Following the definitions for what can be included in the "Frontiers of the Roman Empire" WHS, in may be summarized that the backbone of the man-made component of the cultural landscape includes all kinds of fortifications belonging to the Limes and secondary sites associated directly with them, preserved segments of the Limes road. The cultural landscape, however, expands even further and includes also other man-made elements and features (other complementary sites, the route of the road, sites from other epochs that are situationally related to the Limes), that could eventually make part of the buffer zone of the potential WHS.

To identify all these various groups of elements within the contemporary landscape is a major challenge. Despite many of them are completely invisible, and others are even entirely destroyed, they still have their role for the integrity and the authenticity of the cultural landscape. The placement of the identified sites in the context of the hypothetically reconstructed environment, considering also the chronological span of their existence, their continuity with pre-existent and successor sites is another task needed in order to identify further aspects of the cultural landscape that need to be preserved. The comparison of the historic and contemporary state of the territory could make evident many situational, visual, infrastructural and chronological relationships between the various elements of the cultural landscape. Therefore, the conditions which allowed preservation of these relationships should be maintained or in some cases improved, in order to keep and enhance the existing bonds within the cultural landscape.

The following methodology for analysis of the territory was designed to guide the process of identification of all the above mentioned valuable elements and relationships that make part of the cultural landscape of the Lower Danube Limes in Bulgaria. It is recommended that each fortified location is evaluated according to a series of criteria that describe all possible valuable characteristics that may be available for an individual site (Table 2; Fig. 6). The sum of the results from the analysis performed for every fortified location belonging to the Danube Limes forms the subject of protection. The subject of protection includes material elements that may be man-made or natural, visible or invisible and nonmaterial features: situational, visual, infrastructural and chronological relationships. The analysis of the territory gives the outlines of active risk factors as well whose elimination or at least limitation is essential for the preservation of the cultural landscape.

Valuable material elements of the site itself and its landscape settings

Spatial and visual relationships between sites in the system of Lower Danube Limes, between the main site and secondary sites, between site and landscape

Chronological relations between elements of the system
Such are all visible remains, known and presumed underground structures, that make part of the defence system of the site and its internal constitution; all visible or underground structures belonging to the secondary sites in the vicinity of the main site; landscape elements testifying to a previous condition of the environment, related to the ancient fortified site or to associated secondary sites.

These are visual connections or direct links between the sites (primary and secondary); visual connections or direct links with elements of the landscape: rivers, water bodies, landforms; free visibility corridors within the surrounding area.

These are specific relations of continuity between elements associated with the system that evolved in different time periods.
(1) Visible remains

(2) Preserved remains below the ground. ${ }^{6}$

(3) Preserved historical landscape features.

(4) Readability of the fortified area within the surroundings.

(5) Relation between the site, the Danube River and the opposite bank.

(6) Relation to important elements of the landscape.

(7) Relation between the site and its surrounding territory.

(8) Visual connection with another Danube limes sites.

(9) Relation to Roman roads.

(10) Relation to secondary sites.

(11) Topographical continuity in the same site (presence of cultural layers of different origin)

(12) Functional continuity between two sites (for example when one site succeeds another on a different location) 


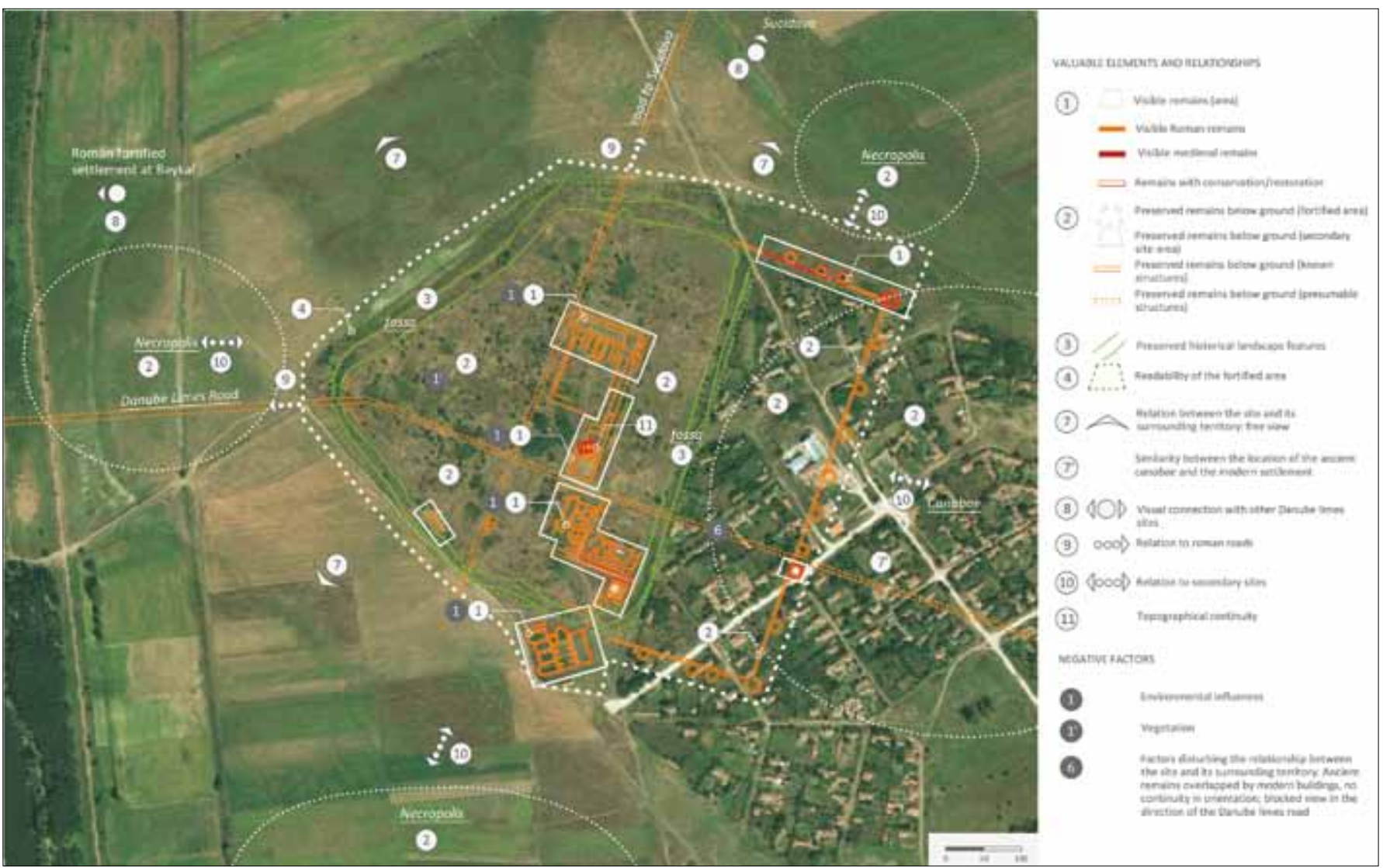

FIGURE 6. Ulpia Oescus. Analysis: Valuable elements and relationships. Negative factors.

\section{Factors affecting negatively the valuable elements and relationships}

The analysis should end with a summary of key issues and active risk factors threatening the integrity and authenticity of the sites themselves and the system of the Danube Limes in Bulgaria in general (Table 3). Such negative factors may compromise the possibility to maintain the characteristics of the heritage needed in order to become part of the world cultural heritage "Frontiers of the Roman Empire." The classification of risk factors is partially adopted by the guidelines for the preparation of

6 The present analysis includes information about potential underground remains coming from written sources and interpretation of historic aerial photos. The knowledge about the underground remains could increase substantially if modern non-destructive methods are applied on the territory: contemporary aerial photography, geophysical surveys, airborne laser scanning (LiDAR) (see Sommer 2008a: 70-3). In urban areas, a useful tool for documentation and management and prognostication of underground remains may be the archaeological cadastre, that include mapping of archaeological evidence (positive results), mapping of all disturbances of the archaeological heritage (negative results), overlay of existing older maps and plans and evidence of written sources (Sommer 2008b: 119-20). management plans (Ringbeck 2008: 35-38). ${ }^{7}$ Some specific issues relevant to the sites belonging to the Lower Danube Limes in Bulgaria are included, as well as issues regarding the sites as elements of a cultural landscape. Factors whose detrimental effect terminated in a past moment and whose effect can be considered irreversible are not included (for example the alteration of the environment due to the drainage of the Danubian lowlands).

7 "Tourism pressure" and "Overpopulation" are risk factors that are not characteristic for the Danube limes sites. They are not established as major tourist attractions and only few of them are situated within populated zones. 


\begin{tabular}{|c|c|c|}
\hline $\begin{array}{l}\text { Factors affecting the } \\
\text { physical integrity of } \\
\text { the site }\end{array}$ & $\begin{array}{l}\text { The negative effects are due to natural } \\
\text { factors (common or having emergency } \\
\text { character) or of human impacts (associated } \\
\text { with the modern development of the } \\
\text { territory or having illegal nature). }\end{array}$ & $\begin{array}{l}\text { (1) Environmental influences: }\left(1^{1}\right) \text { Climatic effects, } \\
\left(1^{2}\right) \text { Groundwater, }\left(1^{3}\right) \text { Natural vegetation; etc. } \\
(2) \text { Natural disasters: }\left(2^{1}\right) \text { Landslides; }\left(2^{2}\right) \text { Flooding; } \\
\left(2^{3}\right) \text { Fire; etc. } \\
\text { (3) Development pressure: }\left(3^{1}\right) \text { Agriculture; }\left(3^{2}\right) \\
\text { Construction; }\left(3^{3}\right) \text { Mining; }\left(3^{4}\right) \text { Forestry; etc. } \\
\text { (4) Malevolent human actions: }\left(4^{1}\right) \text { Treasure } \\
\text { hunting; }\left(4^{2}\right) \text { Vandalism; etc. }\end{array}$ \\
\hline $\begin{array}{l}\text { Factors disturbing } \\
\text { the perception of the } \\
\text { site/system }\end{array}$ & $\begin{array}{l}\text { These factors disturb mostly the visual } \\
\text { integrity of individual sites or the system as } \\
\text { a whole and also the connection between } \\
\text { the sites and their immediate context. } \\
\text { In most cases they can be considered } \\
\text { as derivatives from the "Development } \\
\text { pressure", but due to the nature of the } \\
\text { cultural landscape of WHS Frontiers of the } \\
\text { Roman Empire, a more detailed analysis is } \\
\text { required. }\end{array}$ & $\begin{array}{l}\text { (5) Factors disturbing the perception of the site } \\
\text { (presence of objects alien to the archaeological } \\
\text { site which ruin its aspect) } \\
\text { (6) Factors disturbing the relationship between the } \\
\text { site and its surrounding territory } \\
\text { (7) Factors disturbing the perception of the system } \\
\text { (visual integrity) }\end{array}$ \\
\hline $\begin{array}{l}\text { Factors disturbing } \\
\text { the authenticity of } \\
\text { the site }\end{array}$ & & $\begin{array}{l}\text { (8) Disrespect to the concept of authenticity } \\
\text { (projects for conservation/restoration) }\end{array}$ \\
\hline
\end{tabular}

TABLE 3. Factors affecting negatively the valuable elements and relationships.

The model for the analysis of sites of Lower Danube Limes in Bulgaria here proposed can be considered as guidelines for the study of the current situation of these sites. This is a preliminary phase for the planning of protective measures that must ensure the protection of both the individual sites but also of the entire cultural landscape. The most comprehensive identification of valuable elements and relationships and their inclusion in the "Subject of protection" would contribute to the more effective preservation of the Outstanding Universal Value of the Lower Danube Limes in Bulgaria.

\section{Conclusions}

The proposed methodology for analysis of the sites and territory aims to include a vast variety of evaluation criteria applicable to Danube limes sites, different in respect to their history, present situation and future pro- spective. The analysis performed that way manages to reveal many valuable aspects of the cultural landscape that should be protected, enhanced, interpreted and presented to the public. The methodology puts stress not only on the material components of the cultural landscape - the actual archaeological remains and historical elements of the landscape but also on a variety of spatial, visual and chronological relationships present on the territory. All of them together form the subject of protection.

The analysis outlines also problems and risk factors that currently threaten the heritage, but that may possibly be reversed through positive landscape management. The results of the analysis form the basis for the design of suitable instruments for the conservation, management and socialization of the cultural landscape "Lower Danube Limes in Bulgaria". 


\section{References}

Breeze, D. 2011. The Frontiers of Imperial Rome, Pen \& Sword Books Ltd, Barnsley.

Elton, H. 1996. Frontiers of the Roman Empire, Batsford Ltd, London.

Corine Land Cover Europe 2012. Available at: http:// land.copernicus.eu/pan-european/corine-land-cover/clc2012/view [Accessed 23 Feb. 2018]

Fejérdy, T. and Jilek, S. 2011. Guidelines to Nominate New Danube Limes Sections, In: P. Dyczek, S. Jilek and M. Lemke (eds.), In the footsteps of the Romans - Guidelines to nominate new Danube Limes sections in other Danube countries, Center for Research on the Antiquity of Southeastern Europe, University of Warsaw, Warsaw, 7-24.

FRE SNS 2004. Frontiers of the Roman Empire - Summary nomination statement, English Heritage 2004, In: UNESCO FRE 2008, 394-414.

Jones, R. and Thiel, A. 2008. Guidelines for the mapping of archaeological monuments along the frontiers of the Roman Empire in preparation for their nomination as a World Heritage Site, In: D. Breeze and S. Jilek (eds.), Frontiers of the Roman Empire the European dimension of a World Heritage Site, Historic Scotland, Edinburgh, 99-106.

Protected Areas in Bulgaria. Available at: http://eea.government.bg/flexviewers/pr-areas/index.html? [Accessed 02 Dec. 2017]

Ringbeck, B. 2008. Management Plans for World Heritage Sites. A practical guide, German Commission of UNESCO, Bonn.

Sommer, S. 2008a. Documenting the frontiers of the Roman Empire - work on the Limes in Bavaria, In: D. Breeze and S. Jilek (eds.), Frontiers of the Roman Empire the European dimension of a World Heritage Site, Historic Scotland, Edinburgh, 71-74.
Sommer, S. 2008b. The cadastre project in Straubing (Bavaria), In: D. Breeze and S. Jilek (eds.), Frontiers of the Roman Empire the European dimension of a World Heritage Site, Historic Scotland, Edinburgh, 119-122.

SOUV 2012. Frontiers of the Roman Empire: statement of outstanding universal values, Government UK, Available at: https://www.gov.uk/government/publications/frontiersof-the-roman-empire-hadrians-wall-souv [Accessed 22 Dec. 2017]

Torbatov, S. 2004. The road network in Thrace and Moesia (1st - 3rd century), In: Ivanov R. 2004, Archaeology of the Bulgarian lands, vol.1. Ivray, Sofia, 76-95.

UNESCO FRE 2008. Nomination statement: Frontiers of the Roman Empire 1987, 2005, 2008. UNESCO. Available at: http://whc.unesco.org/en/list/430/documents/ [Accessed 21 Apr. 2017]

UNESCO FRE TL 2016. UNESCO Frontiers of the Roman Empire Tentative lists. Available at: http://whc.unesco. org/en/tentativelists/?action=listtentative \& pattern=Fron tiers+of+the+Roman+Empire\&state=\&theme=\&criteria restrication $=\&$ date_start $=\&$ date_end $=\&$ order $=$ [Accessed 22 Dec. 2017]

UNESCO FRE WHS Slovakia). World Heritage Center, Frontiers of the Roman Empire, Slovakia. UNESCO. Available at: http://whc.unesco.org/en/tentativelists/1732/ [Accessed 22 Dec. 2017] 